\title{
Inhibition of Adenylyl Cyclase Type 5 Prevents L-DOPA- Induced Dyskinesia in an Animal Model of Parkinson's Disease
}

\author{
Hye-Yeon Park, ${ }^{1,3}$ Young-Mi Kang, ${ }^{1}$ Young Kang, ${ }^{1}$ Tae-Shin Park, ${ }^{1,4}$ Young-Kyoung Ryu, ${ }^{1}$ Jung-Hwan Hwang, ${ }^{1}$ \\ Yong-Hoon Kim, ${ }^{1}$ Bong-Hyun Chung, ${ }^{2,5}$ Ki-Hoan Nam, ${ }^{1}$ Mee-Ree Kim, ${ }^{3}$ Chul-Ho Lee, ${ }^{1,5}$ Pyung-Lim Han, ${ }^{6}$ \\ and Kyoung-Shim Kim ${ }^{1,5}$ \\ ${ }^{1}$ Laboratory Animal Resource Center and ${ }^{2}$ BioNanotechnology Research Center, Korea Research Institute of Bioscience and Biotechnology, Daejeon 305- \\ 806, Republic of Korea, Departments of ${ }^{3}$ Food and Nutrition and ${ }^{4}$ Bioscience of Biotechnology, Chung-Nam National University, Daejeon 305-764, Republic \\ of Korea, ${ }^{5}$ University of Science and Technology, Daejeon 305-850, Republic of Korea, and ${ }^{6}$ Department of Brain \& Cognitive Sciences, Ewha Womans \\ University, Seoul 120-750, Republic of Korea
}

The dopamine precursor L-3,4-dihydroxyphenylalanine (L-DOPA) is widely used as a therapeutic choice for the treatment of patients with Parkinson's disease. However, the long-term use of L-DOPA leads to the development of debilitating involuntary movements, called L-DOPA-induced dyskinesia (LID). The cAMP/protein kinase A (PKA) signaling in the striatum is known to play a role in LID. However, from among the nine known adenylyl cyclases (ACs) present in the striatum, the AC that mediates LID remains unknown. To address this issue, we prepared an animal model with unilateral 6-hydroxydopamine lesions in the substantia nigra in wild-type and AC5-knock-out (KO) mice, and examined behavioral responses to short-term or long-term treatment with L-DOPA. Compared with the behavioral responses of wild-type mice, LID was profoundly reduced in AC5-KO mice. The behavioral protection of long-term treatment with L-DOPA in AC5-KO mice was preceded by a decrease in the phosphorylation levels of PKA substrates ERK (extracellular signalregulated kinase) 1/2, MSK1 (mitogen- and stress-activated protein kinase 1), and histone H3, levels of which were all increased in the lesioned striatum of wild-type mice. Consistently, FosB/ $\Delta$ FosB expression, which was induced by long-term L-DOPA treatment in the lesioned striatum, was also decreased in AC5-KO mice. Moreover, suppression of AC5 in the dorsal striatum with lentivirusshRNA-AC5 was sufficient to attenuate LID, suggesting that the AC5-regulated signaling cascade in the striatum mediates LID. These results identify the AC5/cAMP system in the dorsal striatum as a therapeutic target for the treatment of LID in patients with Parkinson's disease.

Key words: adenylyl cyclase; dyskinesia; L-DOPA; Parkinson's disease

\section{Introduction}

The dopamine precursor L-3,4-dihydroxyphenylalanine (L-DOPA) is widely used as a noninvasive therapeutic choice for the treatment of patients with Parkinson's disease (PD). However, the prolonged use of L-DOPA causes abnormal involuntary movements (AIMs), which are known as dyskinesia. However, the un-

Received Feb. 27, 2014; revised June 25, 2014; accepted July 18, 2014.

Author contributions: H.-Y.P., C.-H.L., and K.-S.K. designed research; H.-Y.P., Y.-M.K., Y.K., T.-S.P., Y.-K.R., and K.-S.K. performed research; H.-Y.P., Y.-M.K., J.-H.H., Y.-H.K., B.-H.C., K.-H.N., M.-R.K., C.-H.L., and K.-S.K. contributed unpublished reagents/analytic tools; H.-Y.P., Y.-M.K., Y.K., T.-S.P., J.-H.H., Y.-H.K., B.-H.C., K.-H.N., M.-R.K., P.-L.H., and K.-S.K. analyzed data; H.-Y.P., P.-L.H., and K.-S.K. wrote the paper.

This work was supported by a grant from Korea Research Institute of Bioscience and Biotechnology Research Initiative Program, and the Basic Science Research Program through National Research Foundation of Korea Grants 2012R1A2A2A02014520, 2012R1A2A1A03010177, and 2013M3A9D5072559, which were funded by the government of the Republic of Korea (Ministry of Education, Science \& Technology). We thank Dr. Jae-Ran Lee for the gift of GluR1 antiserum, and Dong-Hee Choi for his excellent technical assistance.

Correspondence should be addressed to Dr. Kyoung-Shim Kim, Laboratory Animal Resource Center, Korea Research Institute of Bioscience and Biotechnology, Gwahak-ro 125, Yuseong-gu, Daejeon 305-806, Republic of Korea. E-mail:kskim@kribb.re.kr.

DOI:10.1523/JNEUROSCI.0864-14.2014

Copyright $\odot 2014$ the authors $\quad 0270-6474 / 14 / 3411744-10 \$ 15.00 / 0$ derlying mechanisms are not clearly understood, and new treatment strategies need to be developed.

Recent studies have demonstrated an involvement of the $D_{1}$ dopamine receptor $\left(\mathrm{D}_{1} \mathrm{R}\right)$ in L-DOPA-induced dyskinesia (LID; Westin et al., 2007; Darmopil et al., 2009). Repeated exposure to L-DOPA triggers a signaling cascade that includes activation of the $\mathrm{D}_{1} \mathrm{R}$ and cAMP-dependent kinase (Picconi et al., 2003; Aubert et al., 2005; Guigoni et al., 2007). The dysregulation of $D_{1} R$ transmission, including altered cAMP production by the $\mathrm{G}_{\text {olf }}$ mediated stimulation of adenylyl cyclase (AC) and the cAMP/ cAMP-dependent phosphoprotein of $32 \mathrm{kDa}$ (DARPP32) have been shown to be involved in LID (Zhuang et al., 2000; Picconi et al., 2003; Corvol et al., 2004). Thr34-phosphorylated (phospho) DARPP32, which causes a reduction in protein phosphatase 1 activity, has been shown to be abnormally high in dyskinetic rats (Greengard et al., 1999; Picconi et al., 2003). In dyskinetic mice, cAMP/cAMP-dependent protein kinase/DARPP32 signaling is sensitized, and this altered CaMKII/DARPP32 signaling results in an increase in the phosphorylation of extracellular signal-regulated protein kinases (ERKs) 1/2, mitogen- and stress-activated kinase 1 
(MSK1), and histone H3 (Santini et al., 2007; Rangel-Barajas et al., 2011; Alcacer et al., 2012).

The loss of dopaminergic neurons in the substantia nigra (SN) triggers extensive remodeling of the basal ganglia, including neurotransmission (Soghomonian and Laprade, 1997; Surmeier et al., 2007). 6-Hydroxydopamine (6-OHDA)-induced lesions of the SN pars compacta (SNc) following L-DOPA treatment have been shown to result in an increase in the activation of the $\mathrm{D}_{1} \mathrm{R}$ and enhanced GABA release; this enhancement is likely related to increased AC activity (Rangel-Barajas et al., 2008). The L-DOPA treatment following the induction of lesions with 6-OHDA increases the expression of $\mathrm{G} \alpha_{\text {olf }}$ and AC type 5/6 in the SN pars reticulata and striatum (Hervé et al., 1993, 2001; Konradi et al., 2004; Rangel-Barajas et al., 2011). In the striatum of dopaminedepleted rats or patients with Parkinson's disease, dopaminestimulated cAMP production is increased (Corvol et al., 2004). These results suggest the importance of $\mathrm{AC}$ in the striatum in regulating LID. The dorsal striatum expresses nine different ACs, among which AC5 is the most abundant AC subtype (Glatt and Snyder, 1993; Lee et al., 2002). Therefore, it is possible that AC5 plays a role in the development and expression of LID, but this hypothesis has not been tested. In the present study, we demonstrated that mice lacking AC5 exhibited attenuated LID. Further, we provide evidence that the reduced LID in AC5-KO mice was preceded by reductions in the L-DOPA and cAMP- and ERKmediated signaling pathway and $\mathrm{Fos} B / \Delta$ FosB expression in the lesioned striatum.

\section{Materials and Methods}

Animals. The AC5-KO mice have been described previously (Lee et al., 2002; Kim et al., 2012a). The AC5-KO mice were backcrossed to $\mathrm{C} 57 \mathrm{BL} / 6 \mathrm{~J}$ mice for $>12$ generations. Homozygote $\left(\mathrm{AC}^{-1-}\right)$ and wildtype $\left(\mathrm{AC}^{+/+}\right)$mice were used in this study. All of the mice were housed in regular polycarbonate plastic cages in a temperature-controlled $\left(21-22^{\circ} \mathrm{C}\right)$ and humidity-controlled $(50-60 \%)$ environment with a $12 \mathrm{~h}$ light/dark cycle (lights on at 7:00 A.M.) and maintained on an ad libitum diet of laboratory chow (Purina) and water. The cages were filled to an approximate depth of $1.5 \mathrm{~cm}$ with bedding made of chopped wood particles (J. Rettenmaier \& Söhne GmbH + Co. KG). Wire-lid hoppers were placed on the cages, and the bedding was changed twice a week. All of the materials were autoclaved, and gamma-irradiated laboratory chow was supplied. The animal room was maintained in a specific pathogenfree condition. The animals in each experimental group were 9-week-old males from three to four litters. Sixty-two $\mathrm{AC} 5^{+/+}$mice and $60 \mathrm{AC} 5^{-1-}$ mice were used in the experiments with 6-OHDA lesions. All of the animals were handled in accordance with The Guidelines of Animal Care of the Korea Research Institute of Bioscience and Biotechnology.

Drugs. 6-OHDA was purchased from Sigma-Aldrich and diluted with $0.02 \%$ ascorbic acid in saline solution. Desipramine $(25 \mathrm{mg} / \mathrm{kg})$, L-DOPA $(20 \mathrm{mg} / \mathrm{kg})$, and the peripheral DOPA decarboxylase inhibitor benserazide hydrochloride $(12 \mathrm{mg} / \mathrm{kg}$ ) were purchased from Sigma-Aldrich and dissolved in saline solution immediately before use. D-Amphetamine (AMPH) was purchased from USP and dissolved in saline solution.

6-OHDA lesions. Mice were anesthetized with a mixture of ketamine hydrochloride and xylazine hydrochloride, as described previously (Kim et al., 2006), and were mounted in a stereotactic frame (Stoelting) that was equipped with a mouse adaptor. Mice were pretreated with desipramine ( $25 \mathrm{mg} / \mathrm{kg}$, i.p.) $30 \mathrm{~min}$ before the surgery to prevent noradrenergic neuron damage. Mice received unilateral injections of 6-OHDA in $3 \mu \mathrm{l}$ of solution $(5 \mu \mathrm{g} / \mu \mathrm{l}$, at the injection speed of $1 \mu \mathrm{l} / \mathrm{min})$ into the left side of the $\mathrm{SN}$ at the following coordinates, according to the mouse brain atlas of Paxinos and Franklin (2008): anteroposterior (AP), $-3.0 \mathrm{~mm}$; lateral, $-1.3 \mathrm{~mm}$; and dorsoventral (DV), $-4.7 \mathrm{~mm}$. Mice were left on a warming plate until they awoke from the anesthesia. Mice that awoke from the anesthesia were returned to their home cages until use. To avoid dehydration, lesioned mice received sterile saline solution ( $10 \mathrm{ml} / \mathrm{kg}$, i.p.) for
$3 \mathrm{~d}$. In addition, during the first week after surgery, food pellets soaked in water were placed in a shallow vessel on the floor of the cages in the evening. In experiments, SNc lesions resulted in a $16 \%$ mortality rate during the first 2 postoperative weeks.

The lesions were assessed at the end of the experiments by determining the striatal levels of tyrosine hydroxylase $(\mathrm{TH})$ with immunohistochemistry. Only the animals that had TH depletions $>80 \%$ in the striatum and $\mathrm{TH}$ reductions $>80 \%$ in the lesioned SNc area compared with the control side were included in the analyses $\left(14 \mathrm{AC}^{+/+}\right.$mice; $13 \mathrm{AC}^{-/-}$ mice).

Cylinder test. All lesioned mice were admitted to the grip strength test and cylinder test. The behavioral effects of the 6-OHDA-induced lesions and subsequent treatments with L-DOPA on sensorimotor function were examined with a cylinder test. Two weeks after the 6-OHDA infusion and $30 \mathrm{~min}$ before the first injection of L-DOPA, each mouse was placed in a transparent acrylic cylinder (diameter, $15 \mathrm{~cm}$; height, $27 \mathrm{~cm}$ ), and the number of contacts with the right or left forepaw on the wall was counted for $5 \mathrm{~min}$ by observers who were blind to mouse genotype and drug treatment. The use of the impaired (right) forelimb was expressed as a percentage of the total number of supporting wall contacts.

Grip strength test. The grip strength test was conducted with a grip strength machine (CCE, Bioseb; $10 \times 16 \mathrm{~cm}$ test grid). Each mouse was allowed to grasp the test grid with his forelimbs and was then yanked by the tail. The grip strengths were expressed as gravity on the screen of the machine. Each mouse was tested 10 times with each test twice before the 6-OHDA injections and 2 weeks after the 6-OHDA injections.

AIMs test. Four weeks after the 6-OHDA injections, lesioned mice were treated with L-DOPA $(20 \mathrm{mg} / \mathrm{kg})$ plus benserazide hydrochloride (12 $\mathrm{mg} / \mathrm{kg}$ ) for $10 \mathrm{~d}$. On the last day of the L-DOPA injections, AIMs were assessed by observers who were blind to mouse genotypes. Mice were individually placed in a separate glass cylinder, and dyskinetic behaviors were assessed for $1 \mathrm{~min}$ (monitoring period) in every $20 \mathrm{~min}$ block for a period of $120 \mathrm{~min}$. The AIM score corresponds to the sum of the individual scores for each AIM subtype. A composite score was obtained by the addition of the scores for axial, limb, and orofacial (ALO) AIMs in consideration of the report that composite AIM scores more closely reflect human dyskinetic behavior compared with the locomotive (LOC) AIM score (Lundblad et al., 2002; Alcacer et al., 2012).

$D$-AMPH-induced rotation test. For mice injected with lentivirus (lenti), D-AMPH-induced rotation was measured 2 weeks after the 6-OHDA injections. Turning behaviors that were induced after D-AMPH $(5 \mathrm{mg} / \mathrm{kg})$ administration were recorded for $60 \mathrm{~min}$ in an observation cylinder (diameter, $20 \mathrm{~cm}$; height $13 \mathrm{~cm}$ ). The number of ipsilateral rotations was analyzed by a SMART video tracking program. The cutoff value was 180 turns for the observation period of $60 \mathrm{~min}$.

Immunohistochemistry. Immunohistochemistry was conducted as described previously (Kim et al., 2012b; 2014). In brief, 30 min after shortterm or long-term treatment with injections of L-DOPA, mice were transcardially perfused with PBS followed by $4 \%$ paraformaldehyde in PBS. Their brains were removed, postfixed overnight, and then cut into $40 \mu \mathrm{m}$ coronal sections with a vibratome (Vibratome VT1000A, Leica Microsystems). Free-floating sections were incubated in PBS containing $3 \% \mathrm{H}_{2} \mathrm{O}_{2}(\mathrm{v} / \mathrm{v})$, rinsed three times in PBS, and blocked with $5 \%$ horse serum (HS) or goat serum (GS) for $1 \mathrm{~h}$ at room temperature. Sections were incubated overnight at $4^{\circ} \mathrm{C}$ with the primary antibodies. The primary antibodies were rabbit polyclonal antibodies for TH [5\% HS; catalog \#P40101-0 (RRID:AB_461064), Pel-Freez], phospho-protein kinase A (PKA) substrate [5\% HS; catalog \#9621S (RRID:AB_330304), Cell Signaling Technology], phospho-ERK1/2 [Thr202/Tyr204, 5\% GS; catalog \#9101S (RRID:AB_331646), Cell Signaling Technology], phospho (Ser10) acetyl (Lys14) histone H3 [pACH3; 5\% GS; catalog \#05-1315 (RRID: AB_10562242), EMD Millipore], and FosB/DFosB [5\% GS; catalog \#2251 (RRID: AB_2106903) Cell Signaling Technology]. After incubation with primary antibodies, sections were rinsed three times in PBS and incubated with biotinylated secondary anti-rabbit IgG (Vector Laboratories), which was followed by incubation with avidin-biotin complex (ABC Kit, Vector Laboratories) and 3,3' -diaminobenzidine (Sigma-Aldrich). Sections containing the dorsal striatum $(0.70 \times 0.52 \mathrm{~mm})$ at $\mathrm{AP}+1.0 \mathrm{~mm}$ and the $\mathrm{SNc}$ at $\mathrm{AP}-3.0$ to $-3.6 \mathrm{~mm}$ from bregma were selected, and 
immunoreactive cells from lesioned and unlesioned striata were counted under a microscope. Immunofluorescence staining was then performed with an Alexa Fluor 594 goat anti-rabbit IgG antibody (secondary antibody, 1:200; Life Technologies). Sections containing the dorsal striatum $(0.35 \times 0.26 \mathrm{~mm})$ at $\mathrm{AP}+1.0 \mathrm{~mm}$ from bregma were selected and incubated with anti-phospho-Thr581-MSK1 [5\% FBS; catalog \#9595 (RRID: AB_2181783), Cell Signaling Technology]. The number of phosphoMSK1-positive cells was counted under a fluorescence microscope (Olympus Corporation). TH-stained area in the dorsal striatum ( +1.0 to $+0.5 \mathrm{~mm}$ from the bregma) was measured in the 6-OHDA-lesioned side and $\mathrm{TH}$-stained neurons in the left and right SNc $(-3.6$ to $-3.0 \mathrm{~mm}$ from the bregma) were counted for three sections per animal by following the procedure described previously (Granado et al., 2008). To avoid double counting of neurons with unusual shapes, TH-stained cells were counted only when their nuclei were visualized in a focal plane. Assessments of the TH-stained area in the dorsal striatum were performed using the MetaMorph image analyzer (Molecular Devices). Qualitative evaluations of immunoreactive cells were performed in a blinded manner in terms of genotype and treatment by following the procedure introduced by Kim et al. (2008).

Western blot analysis. Western blot analysis was described in a previous study (Kim et al., 2012a). Thirty minutes after the last L-DOPA injection, mice were killed, and the brain tissue was quickly removed and homogenized in a homogenization buffer $(50 \mathrm{~mm}$ Tris- $\mathrm{HCl}, \mathrm{pH} 8.0,150 \mathrm{~mm}$ $\mathrm{NaCl}, 1 \%$ Nonidet P-40, $0.1 \%$ SDS, and $0.1 \%$ sodium deoxycholate) containing a cocktail of protease inhibitors (Roche). Protein samples were resolved by SDS-PAGE, and then were transferred onto a PVDF membrane (Bio-Rad). Blots were incubated with primary antibodies followed by secondary antibodies, and specific signals were visualized using an enhanced chemiluminescence kit (Intron Biotechnology). Western blot images were quantified using Quantity One 1-D analysis software, version 4.6.1 (Bio-Rad). Phospho-ERK1/2 [Thr202/Tyr204; catalog \#9101S (RRID:AB_331646), Cell Signaling Technology], ERK1/2 [catalog \#9102S (RRID:AB_10695746), Cell Signaling Technology], phospho-DARPP32 [catalog \#5393S, (RRID:AB_10693947), Cell Signaling Technology], DARPP32 [catalog \#NB100-92027 (RRID:AB_1216582), Novus], phosphoGluA1 [catalog \#04-823 (RRID:AB_1977218), Millipore], GluA1(a gift from Dr. J.R. Lee, KRIBB, Republic of Korea), and actin [catalog \#MAB1501 (RRID:AB_2223041), Millipore], respectively.

Intrastriatal injections of lenti-AC5 shRNA. The lenti-AC5 shRNA and lenti-green fluorescent protein (GFP) control were injected into the dorsal striatum 3 weeks after the lesion was induced with 6-OHDA. Lentiviral shRNA systems were purchased from Thermo Fisher Scientific (RNAi Consortium lentiviral shRNA). The lentiviral system consisted of the human U6 (RNA polymerase III) promoter to drive the expression of shRNA and GFP. The lentivirus was produced by Macrogen Korea. Briefly, the three plasmids, a transfer vector, a VSV-G expression vector, and a gag-pol expression vector were cotransferred into $293 \mathrm{~T}$ cells at a 1:1:1 molar ratio with Lipofectamine Plus (Life Technologies). The culture supernatant containing viral vector particles was harvested $48 \mathrm{~h}$ after transfection, clarified with a $0.45 \mu \mathrm{M}$ membrane filter (Nalge Nunc International), and immediately stored in a deep freezer at $-70^{\circ} \mathrm{C}$. Titers were determined by p24 ELISA or infection into HeLa cells. The GFP expression in the transduced cells was observed and photographed under a fluorescence microscope; the titer was $\sim 1 \times 10^{7}$ transduction units (TU). The viruses were concentrated with the Centricon filtration system (EMD Millipore) and were further concentrated by ultracentrifugation at $80,000 \times g$ for $2 \mathrm{~h}$.

Intrastriatal injections of lenti-AC5 shRNA and lenti-GFP control were performed as described previously (Kim et al., 2008; Seo et al., 2012). In brief, wild-type mice were anesthetized by intraperitoneal injections of a $3.5: 1$ mixture of ketamine $(50 \mathrm{mg} / \mathrm{ml})$ and xylazine hydrochloride $(23.3 \mathrm{mg} / \mathrm{ml})$ at a dose of $1.0 \mu \mathrm{l} / \mathrm{g}$ body weight and placed on a stereotaxic apparatus (Stoelting Europe). The mice were intrastriatally injected on both sides (stereotaxic coordinates in millimeters with reference to bregma: AP, +1 ; mediolateral, \pm 1.8 ; DV,-3.6 ) with a total of 3 $\mu \mathrm{l}$ of lenti-AC5 $\left(1 \times 10^{9} \mathrm{TU}\right.$ in total $)$ or lenti-GFP with the same titer $\left(1 \times 10^{9} \mathrm{TU}\right)$ at a speed of $1 \mu \mathrm{l} / \mathrm{min}$ with a 28 gauge needle. After $5 \mathrm{~min}$, the needle was removed with three intermediate steps for $3 \mathrm{~min}$ to min- imize backflow, and the injected mice were kept on a warming pad until they awoke. Surgically manipulated mice that awoke from anesthesia were returned to their home cages. The mice received L-DOPA $(20 \mathrm{mg} / \mathrm{kg})$ starting from $7 \mathrm{~d}$ after viral injection for consecutive $10 \mathrm{~d}$, and behavioral assessments were performed $17 \mathrm{~d}$ after viral injection.

Real-time RT-PCR analyses. RNA preparation and real-time quantitative PCR (qPCR) were performed as described previously (Kim et al., 2012a). Total RNA was purified from the dorsal striatum using TRI reagent (Sigma). Prepared RNA was treated with DNase I to avoid genomic contamination. Reverse transcription was performed using a Promega RT-PCR kit (Promega). PCR was prepared with a mix of $5 \mu \mathrm{l}$ of $2 \times$ SYBR Green mix (Applied Biosystems), $1 \mu \mathrm{l}$ each of $5 \mathrm{pmol} / \mathrm{ml}$ forward and reverse primers, and $2 \mu \mathrm{l}$ of $\mathrm{cDNA}$ (1:50 dilution of the cDNA synthesized from $1 \mu \mathrm{g}$ of total RNA and eluted in $15 \mu \mathrm{l})$ in a volume of $10 \mu \mathrm{l}$ using the StepOne Real-Time PCR System (Applied Biosystems). The cycle number at which the fluorescence emission exceeds the fixed threshold was defined as the threshold cycle. The cycle was performed as follows: $10 \mathrm{~min}$ at $95^{\circ} \mathrm{C}$, followed by 41 cycles of $20 \mathrm{~s}$ at $95^{\circ} \mathrm{C}, 30 \mathrm{~s}$ at $60^{\circ} \mathrm{C}$, and $20 \mathrm{~s}$ at $72^{\circ} \mathrm{C}$. The difference in amplification fold was calculated based on real-time qPCR amplification of the target gene versus GAPDH as a reference using the built-in software of the Gene Expression Analysis for StepOne Software, version 2.1 (Applied Biosystems). Real-time qPCR was repeated four times. The primer sets of AC5 (5' -GGC AGC TGG AAA AGA TCA AG-3' and 5' -GCA ATA GCC TTG ATG TGG GT- $\left.3^{\prime}\right)$ and GAPDH (5'-AGG TCG GTG TGA ACG GAT TTG-3' and 5'-TGT AGA CCA TGT AGT TGA GGT CA-3') were used.

Statistical analysis. PRISM software (GraphPad Software) was used to perform the statistical analyses. Two-sample comparisons were conducted with the Student's $t$ test, while multiple comparisons were made with a two-way ANOVA followed by a Bonferroni post hoc test, or with a one-way ANOVA followed by a Tukey-Kramer post hoc test. All of the results are presented as the mean \pm SEM. Any difference with a $p$ value of $<0.05$ was considered to be statistically significant.

\section{Results}

The 6-OHDA lesions produced comparable motor function deficits in wild-type and $\mathrm{AC}^{-1-}$ mice

Injections of 6-OHDA into the $\mathrm{SNc}$ reduced $\mathrm{TH}$ immunoreactivity in the $\mathrm{SNc}$ and in most areas of the dorsal striatum in $\mathrm{AC} 5^{+/+}$ and $\mathrm{AC} 5^{-1-}$ mice (Fig. $1 \mathrm{~A}$ ). TH depletion levels in the lesioned side were $92.6 \pm 1.59 \%$ and $93.66 \pm 1.62 \%$, respectively, in $\mathrm{AC}^{+/+}$and $\mathrm{AC}^{-1-}$ mice (Fig. $1 B$ ). Mice that showed TH depletion levels of $<80 \%$ were excluded from the final analysis. Two weeks after the injection, the number of wall contacts with the forelimb in the cylinder test and the grip strength levels of the forelimbs were measured. $\mathrm{AC} 5^{+/+}$and $\mathrm{AC} 5^{-1-}$ mice showed a significant decrease in the grip strength of the forelimb after the lesion was induced with 6-OHDA (Fig. 1C), and they displayed a marked reduction in the use of the forelimb on the side contralateral to the lesion side, indicating the typical hypokinetic effects of a 6-OHDA lesion (Fig. 1D).

\section{LID was attenuated in $\mathrm{AC5} 5^{-/-}$mice}

We examined the pharmacotherapeutic effects of L-DOPA in 6-OHDA-lesioned $\mathrm{AC} 5^{+/+}$and $\mathrm{AC} 5^{-1-}$ mice. In the cylinder test that was performed $30 \mathrm{~min}$ after the first treatment with L-DOPA, AC $5^{+/+}$mice showed a significant recovery in forelimb usage (Fig. $1 D$ ). The therapeutic effects of L-DOPA were preserved in $\mathrm{AC}^{-1-}$ mice (Fig. $1 D$ ).

The 6-OHDA-lesioned mice were then treated daily with L-DOPA ( $20 \mathrm{mg} / \mathrm{kg}$ in combination with $12 \mathrm{mg} / \mathrm{kg}$ benserazide), and the AIM scores were determined $10 \mathrm{~d}$ later. The duration of drug administration was based on previous studies (Lundblad et al., 2005; Santini et al., 2007; Alcacer et al., 2012). A significant difference between $\mathrm{AC}^{+/+}$and $\mathrm{AC} 5^{-/-}$mice in ALO AIMs in response to long-term L-DOPA treatment was observed (Fig. 
A

B
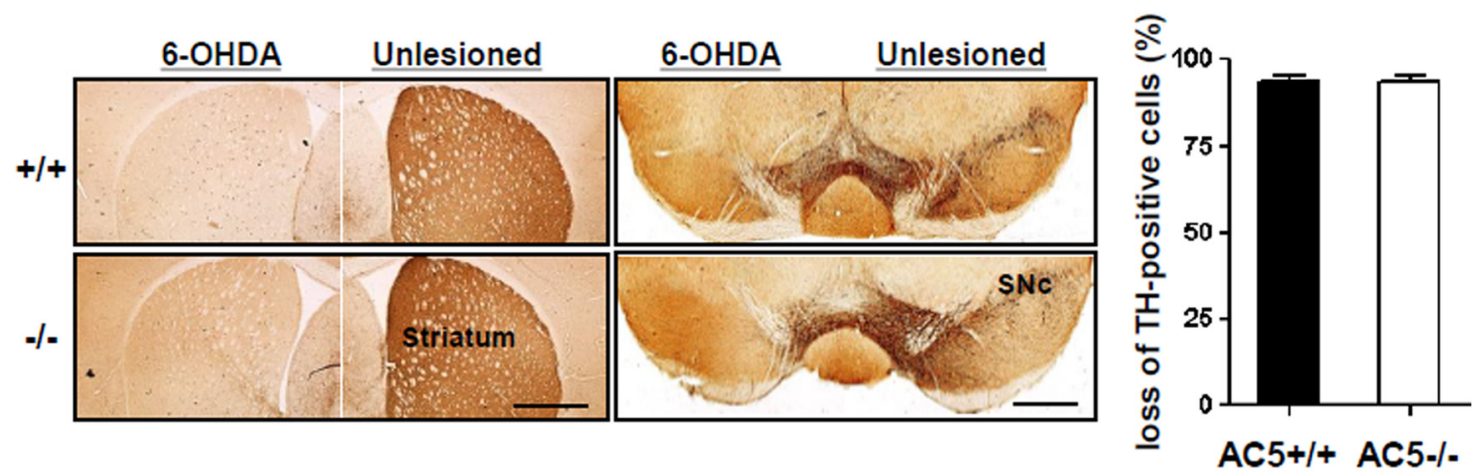

C

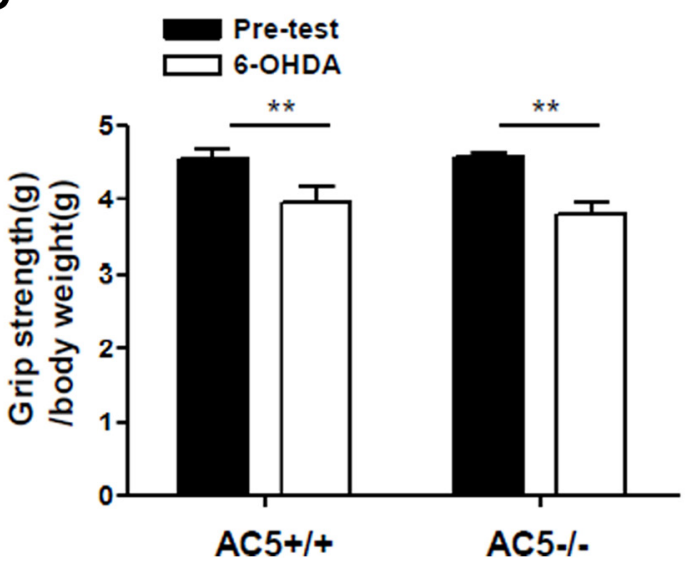

D

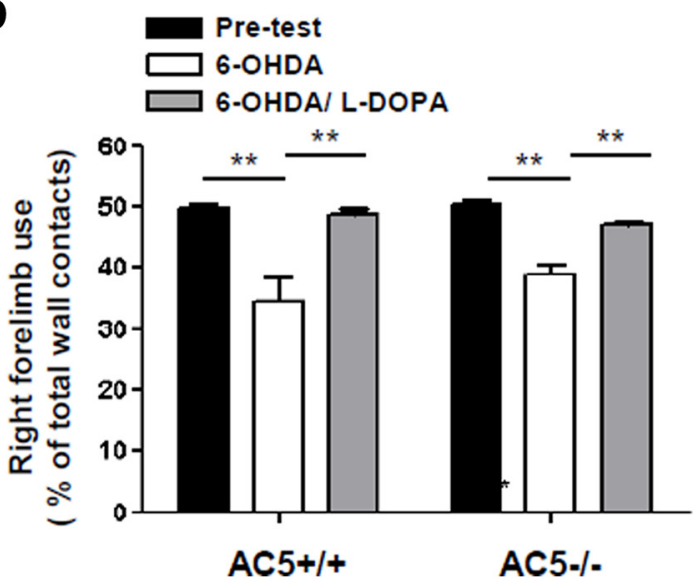

Figure 1. Effects of 6-OHDA lesions in $A C 5^{+/+}$and $A C 5^{-1-}$ mice. $A$, TH immunoreactivity on the 6-OHDA-lesioned and unlesioned sides in the striatum and $S N C$ of $A C 5^{+/+}$and $A C 5^{-1-}$ mice. Scale bar, $500 \mu \mathrm{m}$. $B$, Percentage loss of SNc TH-positive cells on the lesioned side compared with the unlesioned side of AC5 ${ }^{+/+}$and AC5 ${ }^{-/-}$mice $(n=13-14$; Student's $t$ test, $p=0.9604, t=$ 0.4655). C, Forelimb grip strength $(g)$ of $A C 5^{+/+}$and AC5 ${ }^{-1-}$ mice before and after 6-OHDA administration $(n=13-14)$. ${ }^{* *} p<0.01$ versus before and after 6-0HDA lesions. Tw0-way ANOVA: effect of genotypes, $F_{(1,25)}=0.26, p=0.6115$; effect of surgery, $F_{(1,25)}=36.30, p<0.0001$; interaction, $F_{(1,25)}=0.16, p=0.6898$, followed by Bonferroni test. $D$, Right forelimb use of AC5 $+/+$ and $\mathrm{AC5}{ }^{-1-}$ mice in the cylinder test before and after 6-OHDA administration, and after the first treatment of L-DOPA $(n=13-14)$. ${ }^{* *} p<0.01 .0$ ne-way ANOVA followed by a Tukey post hoc test.

$2 A)$. The LOC composite score was also significantly reduced in AC5 ${ }^{-1-}$ mice (Fig. 2B). The total AIM score (Fig. 2C) and the time course of the L-DOPA effects (Fig. 2D) were significantly affected by the AC5 deficiency. These results suggested that the deletion of AC5 changed the severity of the dyskinesia that was induced by the $10 \mathrm{~d}$ treatment with L-DOPA. We did not observe any correlation between the reduction of TH and the severity of AIMs in either genotype (Fig. 2E,F).

AC5 KO suppressed the activation of PKA, ERK, MSK1, and histone $\mathrm{H} 3$, which are key molecules in LID

The cAMP-PKA signaling pathway is upregulated in the striatum of 6-OHDA-lesioned model mice (Rangel-Barajas et al., 2011) and in mice with high dyskinesia (Santini et al., 2007). Thirty minutes after the administration of L-DOPA on the $11 \mathrm{~d}$ L-DOPA treatment schedule, the numbers of neurons that expressed a phosphorylated form of the PKA substrate consensus sequence (Sindreu et al., 2007) were increased in the lesioned striatum of wild-type mice (Fig. $3 A, B$ ) and in $A C 5^{-1-}$ mice. However, the increase in $\mathrm{AC} 5^{-1-}$ mice was significantly lower than that in AC5 ${ }^{+/+}$mice, implicating the attenuation of cAMP-PKA signaling activity in $\mathrm{AC5} 5^{-1-}$ mice. To be convinced further, we examined by immunoblotting the phosphorylation levels of the PKA substrates, AMPA receptor subunit GluA1 at Ser845 (Snyder et al., 2000), and DARPP32 at Thr34 (Hemmings et al., 1984). In the lesioned striatum of $\mathrm{AC}^{+/+}$mice, long-term L-DOPA treatment increased the phosphorylation levels of GluA1 and DARPP32 compared with those in the unlesioned striatum (Fig. $3 F, G)$. However, no such increase was found in $\mathrm{AC} 5^{-I-}$ mice (Fig. $3 F, G$ ).

The ERK cascade is another cellular event that is strongly activated by L-DOPA in the lesioned striatum of the mouse (Gerfen et al., 2002; Pavón et al., 2006). Pretreatment with an ERK inhibitor (SL327) in 6-OHDA-lesioned mice has been shown to reduce LID (Santini et al., 2007). The number of neurons that were stained by phospho-ERK on the lesioned side was markedly increased in wild-type mice (Fig. $4 A, C$ ), whereas the number of neurons that had positive results of staining for phospho-ERK in the lesioned striatum in $\mathrm{AC} 5^{-1-}$ mice were much lower than those in wild-type mice (Fig. 4C). We examined by immunoblotting the levels of phospho-ERK. In the lesioned striatum of $\mathrm{AC}^{+/+}$mice, long-term L-DOPA treatment increased the level of phospho-ERK compared with that in the unlesioned striatum (Fig. $3 H, I$ ). This increase was present in $\mathrm{AC} 5^{-1-}$ mice, but the level was not significant (Fig. $3 H, I$ ).

Activation of ERK sequentially results in the phosphorylation of MSK1 and histone H3 (Deak et al., 1998; Soloaga et al., 2003; Brami-Cherrier et al., 2005; Santini et al., 2007). The severity of the AIMs was correlated with the upregulated levels of phosphoMSK1 and phospho-histone $\mathrm{H} 3$ in the lesioned striatum in wildtype mice (Santini et al., 2007). In fact, $30 \mathrm{~min}$ after the administration of L-DOPA on the $11 \mathrm{~d}$ L-DOPA treatment schedule, the number of neurons that were positive for phospho-MSK1 on the lesioned side was increased in wild-type mice, but not in $\mathrm{AC}^{-1-}$ mice (Fig. 4A,D). Similarly, the number of neurons that 
A

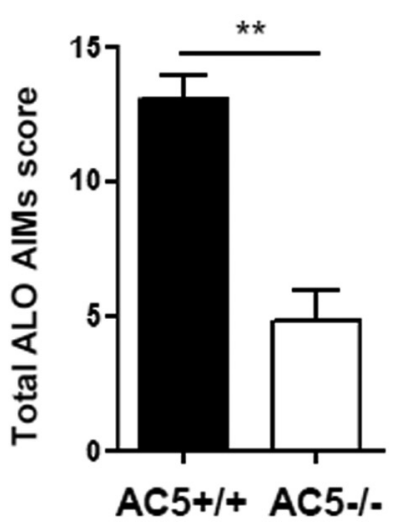

B

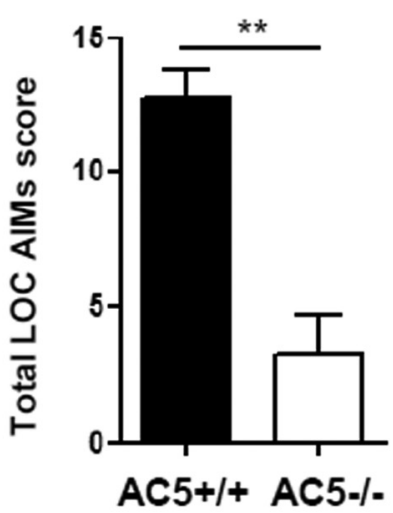

C
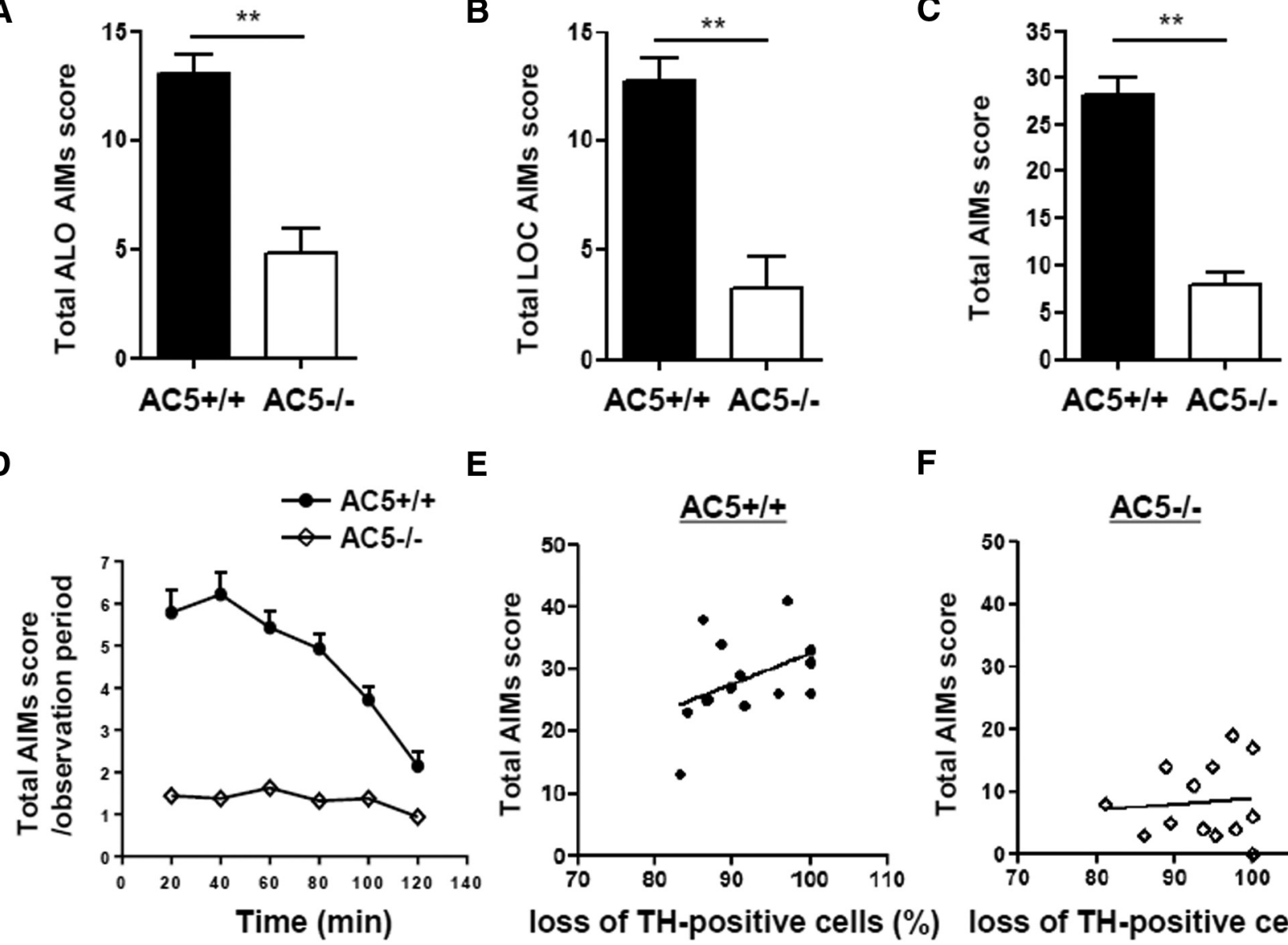

$\mathbf{F}$

E

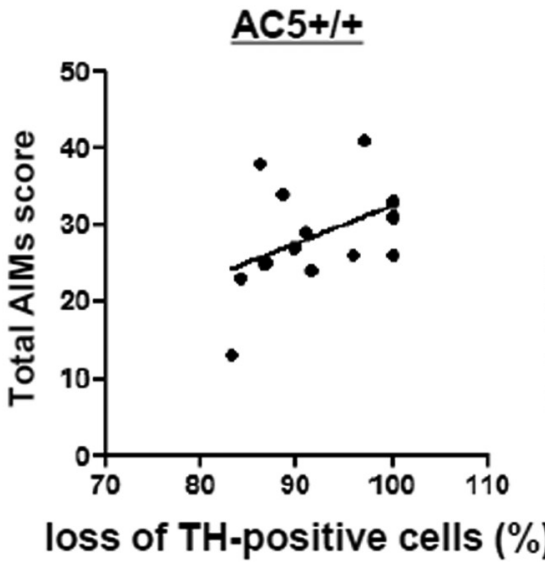

AC5-/-

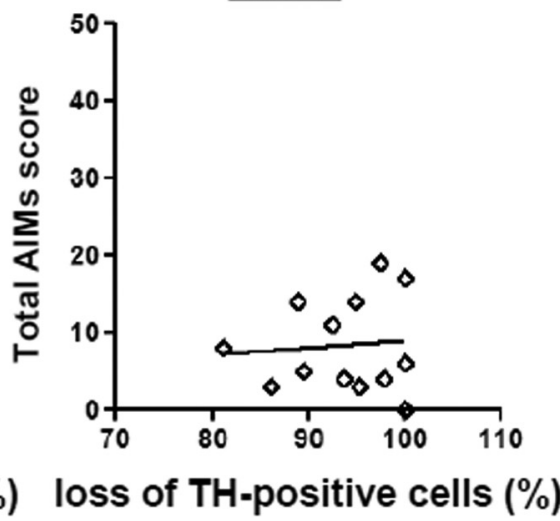

Figure 2. LID is attenuated in 6-OHDA-lesioned AC5 ${ }^{-1-}$ mice. $A$, Sum of ALO AIMs that were scored during the 120 min period after the last L-DOPA administration. Comparison between $\mathrm{AC5}^{+/+}(n=14)$ and AC5 ${ }^{-1-}(n=13)$ mice. Student's test, $p<0.01$. B , Sum of LOC AIMs that were scored during the 120 min period after L-DOPA administration in the same animals. Student's $t$ test, $p<0.01$. C, Total AIMs (sum of LOC and ALO AIMs) that were scored during the 120 min period after the last L-DOPA administration. Student's $t$ test, $p<0.01$. D, Time course of total AIMs that were scored every 20 min over a period of 120 min after the last L-DOPA administration $(n=13-14)$. Tw0-way ANOVA: effect of genotypes, $F_{(1,125)}=60.43, p<0.0001$; effect of time, $F_{(5,125)}=19.26, p<0.0001$; interaction, $F_{(5,125)}=13.25, p<0.0001 . \boldsymbol{E}, \boldsymbol{F}$, Simple linear regression analysis showing the absence of a correlation between the depletion of TH and AIM scores in 6 -OHDA-lesioned $\mathrm{AC5} 5^{-1-}$ mice, although TH immunoreactivity in the lesioned SNc was reduced by $>80 \%\left(\mathrm{AC} 5^{+/+}\right.$mice: $r=0.184, p=0.1259 ; \mathrm{AC} 5^{-1-}$ mice: $\left.r=0.007, p=0.7791\right)$.

were positive to phospho-Ser10-acetylLys14 histone $\mathrm{H} 3$ in the lesioned striatum was increased in wild-type mice, but not in AC5 $^{-1-}$ mice (Fig. $4 A, E$ ).

The effects of short-term L-DOPA treatment were comparable between $\mathrm{AC}^{+/+}$mice and $\mathrm{AC} 5^{-/-}$mice

The short-term administration of L-DOPA in 6-OHDA-lesioned mice has been shown to upregulate cAMP and ERK signaling cascades (Santini et al., 2007; Alcacer et al., 2012). Thirty minutes after a single administration of L-DOPA, the numbers of cells that were positive for the phosphorylated forms of the PKA substrates, p-ERK1/2, p-MSK1, and phospho-Ser10-acetylLys14 histone H3 on the 6-OHDA-lesioned side of the striatum were dramatically increased in $\mathrm{AC}^{+/+}$mice (Fig. $4 A-C$ ). In contrast, the number of cells that were positive for the phosphorylated form of each factor in the lesioned striatum was not increased in $\mathrm{AC} 5^{-1-}$ mice (Fig. 4A-D).

FosB $/ \Delta$ FosB expression after long-term L-DOPA was decreased in $\mathrm{AC} 5^{-1-}$ mice

The phosphorylation of MSK1 and histone $\mathrm{H} 3$ results in changes in chromatin structure and transcriptional regulation (Nowak and Corces, 2004). FosB/ $\Delta$ FosB is induced in dynorphin-positive striatal neurons, and its expression is regulated by the activation of ERK1/2 (Andersson et al., 1999; Pavón et al., 2006; Fasano et al., 2010). In fact, the number of FosB $/ \Delta$ FosB-positive cells that were induced by short-term L-DOPA in the lesioned striatum compared with that on the unlesioned side was increased in $\mathrm{AC} 5^{+/+}$ mice and in $\mathrm{AC} 5^{-1-}$ mice (Fig. $5 B$ ). The long-term administration of L-DOPA increased ERK1/2 phosphorylation (Fig. $4 B$ ), and this has been shown to correlate with the overexpression of Fos $B / \Delta$ FosB in the lesioned striatum (Pavón et al., 2006). Thirty minutes after the administration of L-DOPA on the $11 \mathrm{~d}$ L-DOPA treatment schedule, the number of FosB $/ \Delta$ FosB-positive cells on the lesioned side was increased in wild-type mice (Fig. $5 A, C$ ). The number of FosB $/ \Delta$ FosB-positive cells on the lesioned side was also increased in $\mathrm{AC} 5^{-1-}$ mice, but the induction level in $\mathrm{AC} 5^{-1-}$ mice was significantly reduced compared with that in $\mathrm{AC} 5^{+/+}$mice (Fig. $5 C$ ). In addition, the number of FosB/ $\Delta$ FosB-positive cells that were induced by long-term L-DOPA treatment in the lesioned striatum in $\mathrm{AC} 5^{-1-}$ mice was comparable to that induced by short-term L-DOPA treatment (Fig. $5 B, C$ ).

Lenti-AC5 shRNA injections in the dorsal striatum in $\mathrm{AC} 5^{+/+}$ mice decreased ALO AIM scores

To examine whether the reduced expression of AC5 in the striatum was responsible for the lowering effects on LID, we injected lenti-AC5 shRNA into the dorsal striatum. Two weeks after le- 
A
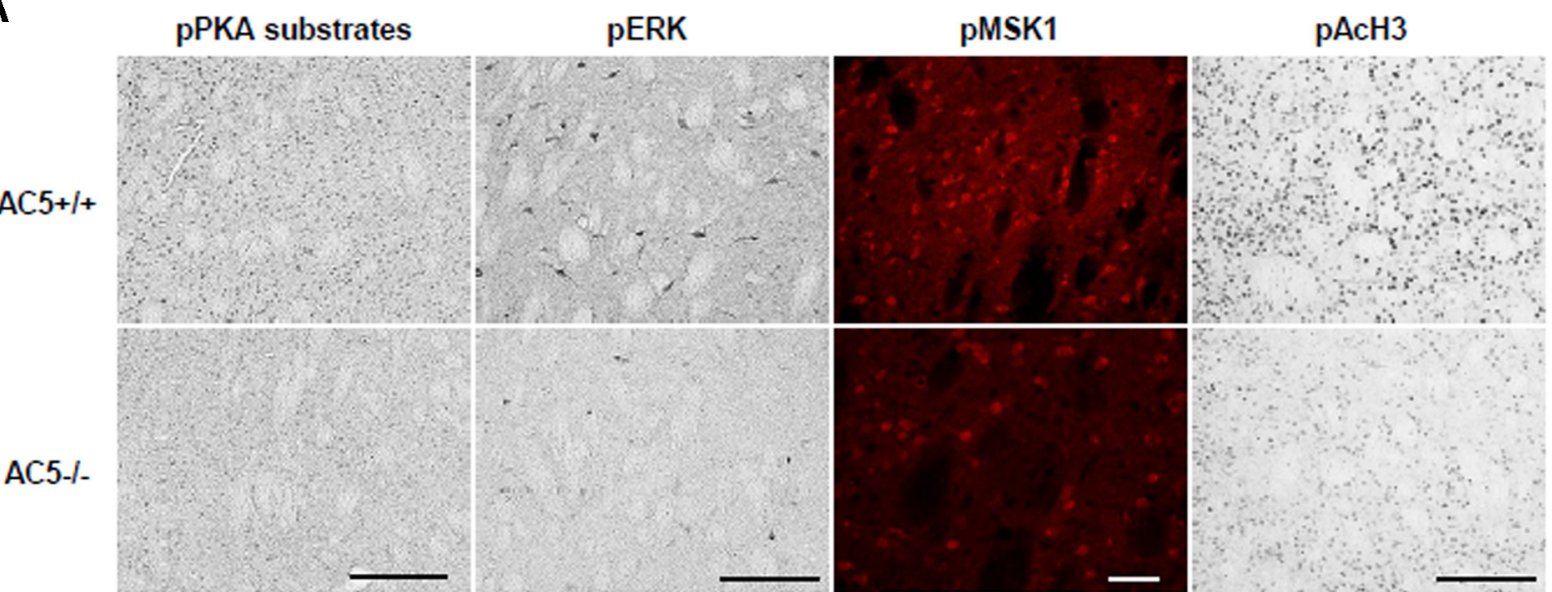

B

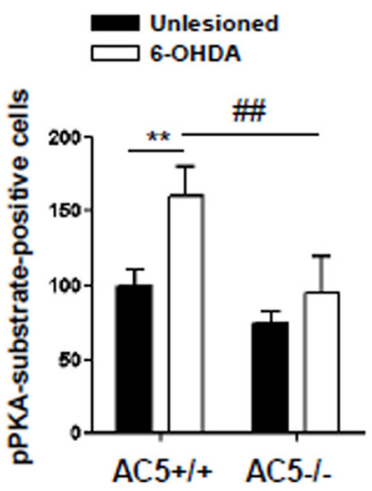

F

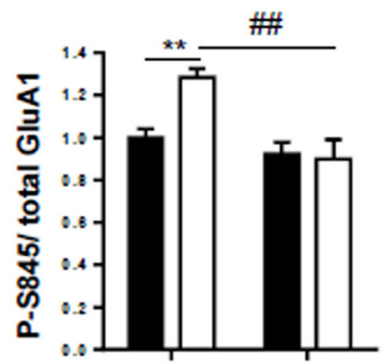

pGluA1

GluA1

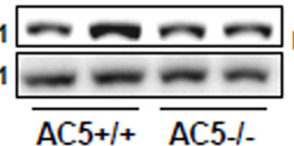

C

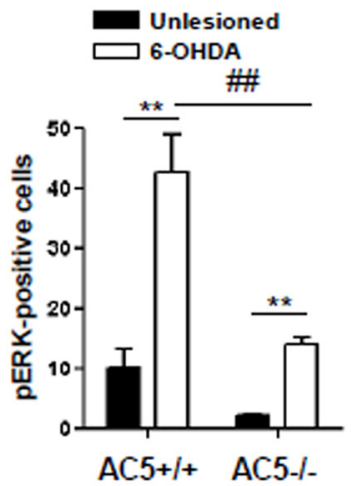

D

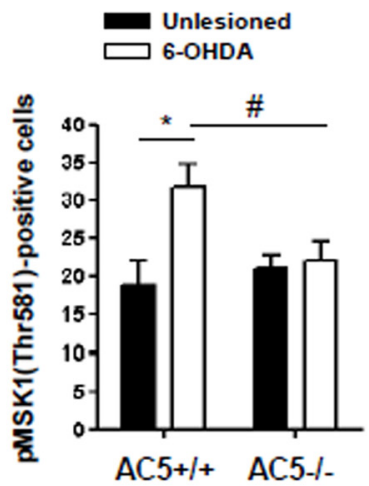

H

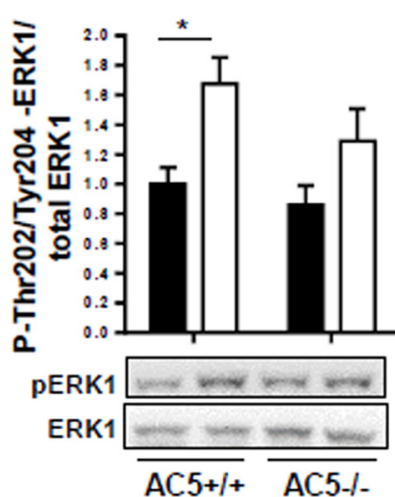

E

Unlesioned 6-OHDA

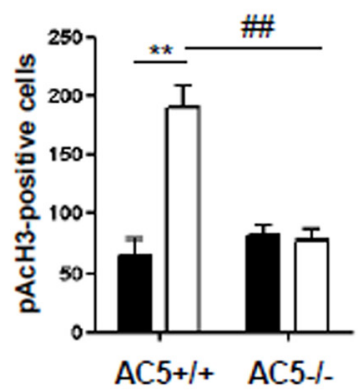

I

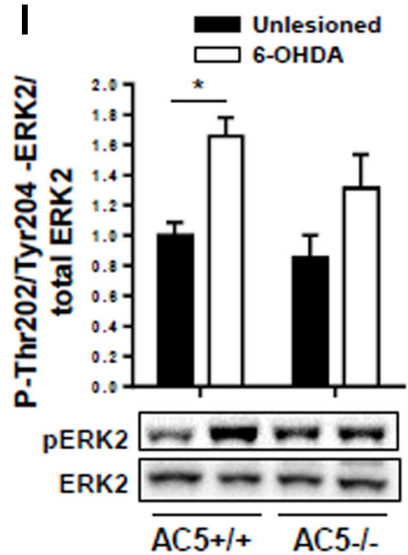

Figure 3. 6-OHDA-induced signaling changes were significantly reduced in the 6-OHDA-lesioned dorsal striatum of AC5 ${ }^{-1-}$ mice. $A$, Phospho-PKA substrate, pERK1/2-, pACH3, and pMSK1 immunoreactivity in the 6-OHDA-lesioned dorsal striata of $A C 5^{+/+}$and $A C 5^{-/-}$mice 30 min after the last injection of L-DOPA/benserazide. $\boldsymbol{B}$, Number of phospho-PKA substrate-positive cells in the dorsolateral striata of $A C 5^{+/+}$and AC5 ${ }^{-/-}$mice $(n=13-14)$. Two-way ANOVA: effect of genotypes, $F_{(1,50)}=17.36, p<0.0001$; effect of the lesion, $F_{(1,50)}=39.17, p<0.0001$; interaction, $F_{(1,50)}=3.92, p>0.05$. Post hoc comparison (with Bonferroni test): ${ }^{* *} p<0.01,6-0$ HDA-lesioned versus unlesioned striata; \#\#p $<0.01, A C 5^{+1+}$ versus AC5 ${ }^{-1-}$ mice. Scale bar, $100 \mu m$. $C$, Number of phospho-ERK1/2-positive cells in the dorsolateral striata of $A C 5^{+/+}$and $A C 5^{-1-}$ mice $(n=13-14)$. Tw0-way ANOVA: effect of genotypes, $F_{(1,50)}=27.73, p<0.001$; effect of the lesion, $F_{(1,50)}=39.73, p<0.001$; interaction, $F_{(1,50)}=8.65, p<0.01$. Post hoc comparison (with Bonferroni test): ${ }^{* *} p<0.01,6-0 \mathrm{HDA}$-lesioned versus unlesioned; $\# p<0.01, \mathrm{AC5}{ }^{+1+}$ versus $A C 5^{-/-} . D$, Number of phospho-MSK1-positive cells in the dorsolateral striata of AC5 ${ }^{+/+}$and AC5 ${ }^{-1-}$ mice $(n=13-14)$. Tw0-way AN0VA: effect of genotypes, $F_{(1,50)}=1.68, p=0.200 ;$ effect of the lesion, $F_{(1,50)}=4.05, p<0.05$; interaction, $F_{(1,50)}=5.63, p<0.05$. Post hoc comparison (with Bonferroni test): ${ }^{*} p<0.05,6-0 \mathrm{HDA}$-lesioned versus unlesioned striata; $\# p<0.01$, AC5 $+/+$ versus $A C 5^{-I-}$ mice. $\boldsymbol{E}$, Number of phospho-ACH3-positive cells in the dorsolateral striata of AC5 ${ }^{+/+}$and AC5 ${ }^{-/-}$mice $(n=13-14)$. Tw0-way ANOVA: effect of genotypes, $F_{(1,48)}=12.64, p<$ 0.0001; effect of the lesion, $F_{(1,48)}=18.68, p<0.0001$; interaction, $F_{(1,48)}=21.26, p<0.0001$. Post hoc comparison (with Bonferroni test): ${ }^{* *} p<0.01,6-0$ HDA-lesioned versus unlesioned striata; \#\#p $<0.01, A C 5^{+/+}$versus AC5 ${ }^{-1-}$ mice. $\boldsymbol{F}, \mathbf{G}$, Western blots showing the levels of p-Ser845-GluA1 (F) and p-Thr34-DARPP32 (G) in 6-0HDA-lesioned and unlesioned dorsal striata of $\mathrm{AC} 5^{+/+}$and $\mathrm{AC5} 5^{-1-}$ mice 30 min after the last injection of L-DOPA/benserazide $(n=9-12)$. Two-way ANOVA with Bonferroni test: ${ }^{* *} p<0.01,6-0 \mathrm{HDA}$-lesioned versus unlesioned striata; $\# p<$ 0.05 and \#\#p $<0.01, A C 5^{+/+}$versus $A C 5^{-/-}$mice. A significant interaction between genotype and treatment $\left(\boldsymbol{F}, F_{(1,40)}=7.76, p<0.01 ; \boldsymbol{G}, F_{(1,34)}=4.65, p=0.0383\right)$. $\boldsymbol{H}, \boldsymbol{I}, \mathbf{W e s t e r n}$ blots showing the levels of p-Thr202/Tyr204-ERK1 $(\boldsymbol{H})$ and p-Thr202/Tyr204-ERK2 $(\boldsymbol{I})$ in 6-0HDA-lesioned and unlesioned dorsal striata of AC5 ${ }^{+/+}$and AC5 ${ }^{-/-}$mice 30 min after the last injection of L-DOPA/benserazide ( $n=10-12)$. Two-way ANOVA with Bonferroni test: ${ }^{*} p<0.05,6-0$ HDA-lesioned versus unlesioned striata. $\boldsymbol{H}$, pERK1: effect of lesion, $F_{(1,40)}=11.45, p<0.01$; effect of genotype, $F_{(1,40)}=0.1153, p>0.05$; interaction, $F_{(1,40)}=0.57 ; p>0.05 . I$, pERK2: effect of lesion, $F_{(1,40)}=14.37, p<0.001$; effect of genotype, $F_{(1,40)}=2.80, p>0.05 ;$ interaction, $F_{(1,40)}=0.45 ; p>0.05$. 
A

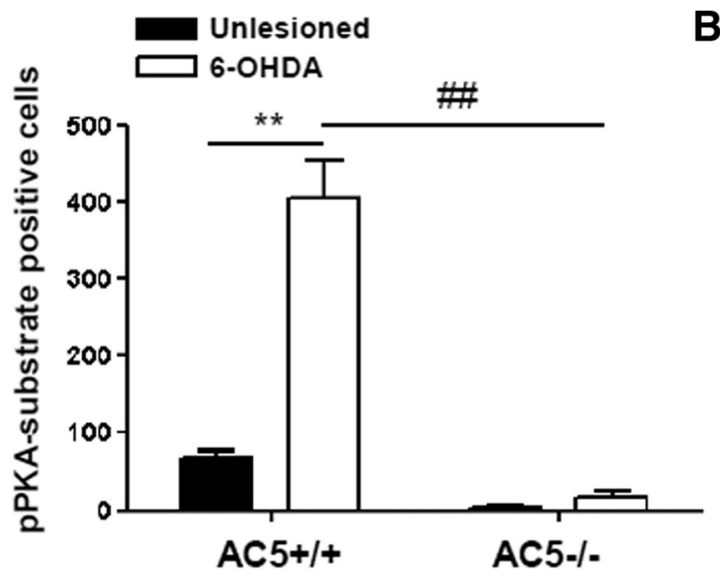

C

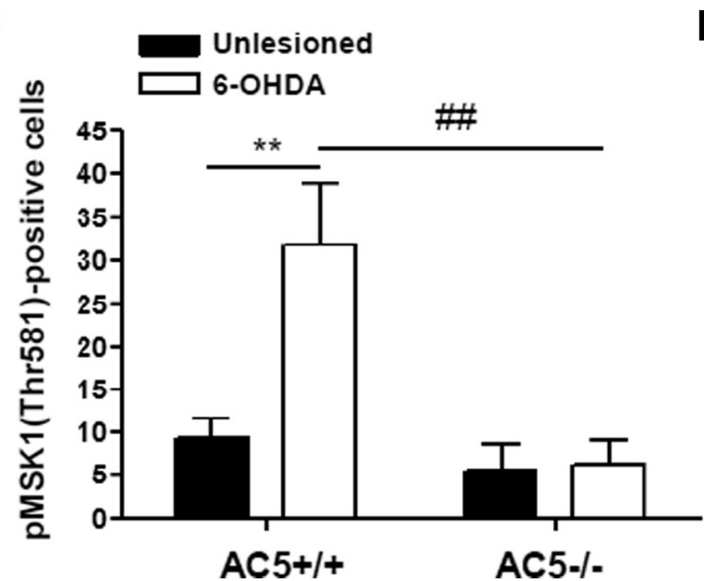

B

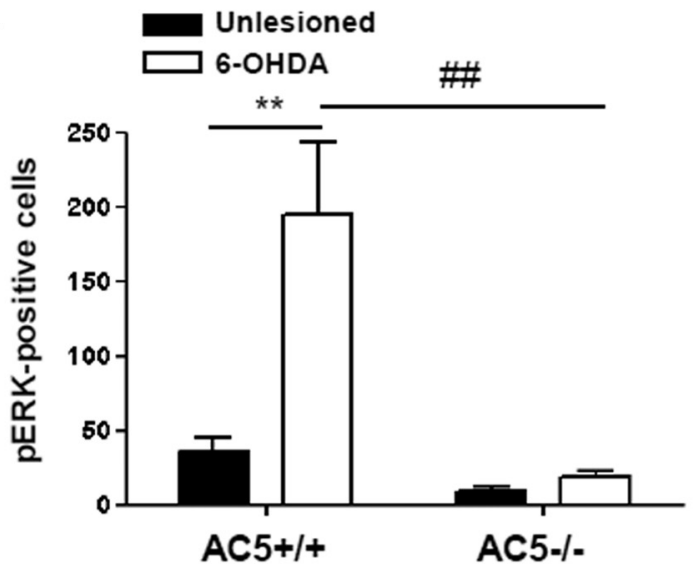

D
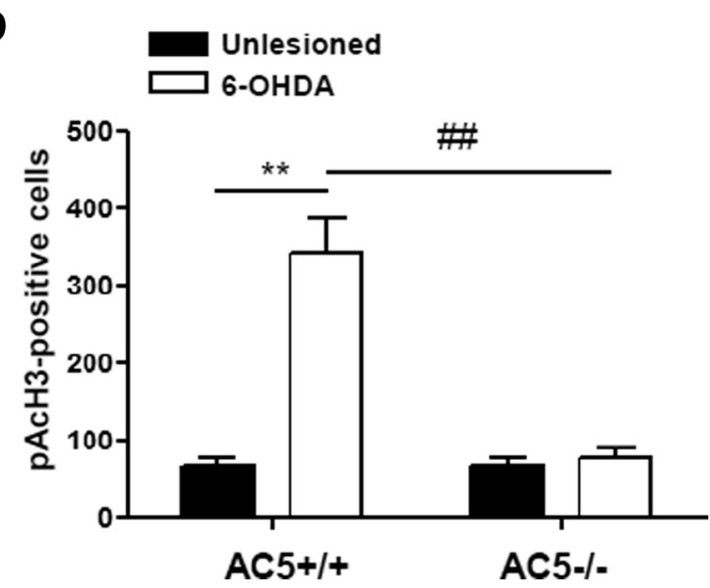

Figure 4. CAMP/PKA and ERK signaling in short-term L-DOPA treatment. $\boldsymbol{A}-\boldsymbol{D}$, The number of cells positive to pPKA substrates $(\boldsymbol{A}), \mathrm{p}$-ERK1/2 $(\boldsymbol{B}), \operatorname{pMSK1}(\boldsymbol{C})$, and pACH3 $(\boldsymbol{D})$ neurons in the lesioned and unlesioned dorsolateral striata of $\mathrm{AC5}{ }^{+/+}$and $\mathrm{AC5}{ }^{-/-}$mice $(n=6-7)$. $^{* *} p<0.01,6-0 \mathrm{HDA}$-lesioned versus unlesioned striata; \#\# $<0.01, \mathrm{AC5}^{+/+}$versus $\mathrm{AC5}{ }^{-1-}$ mice. A significant interaction was found between genotype and treatment $\left(\boldsymbol{A}, F_{(1,22)}=35.81, p<0.001 ; \boldsymbol{B}, F_{(1,22)}=9.79, p<0.01 ; C_{1}, F_{(1,22)}=5.86, p<0.05 ; \boldsymbol{D}, F_{(1,22)}=26.16, p<0.0001\right)$.

A

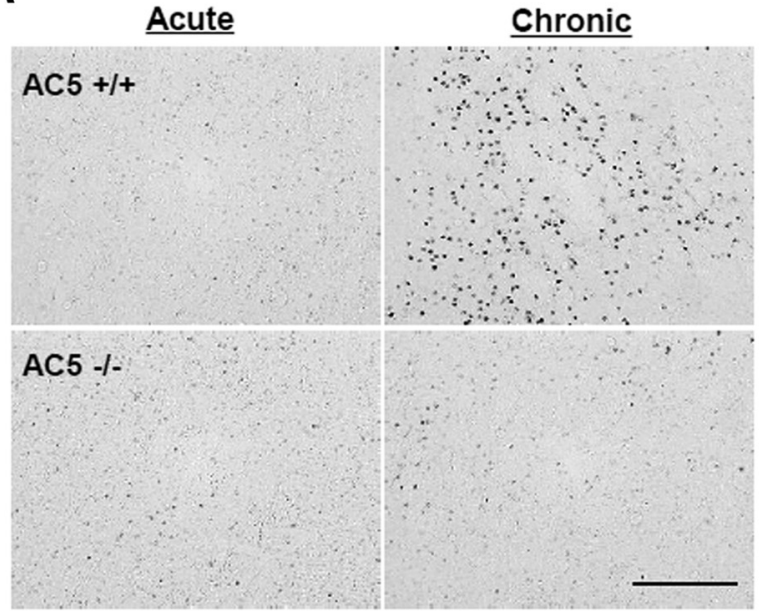

B

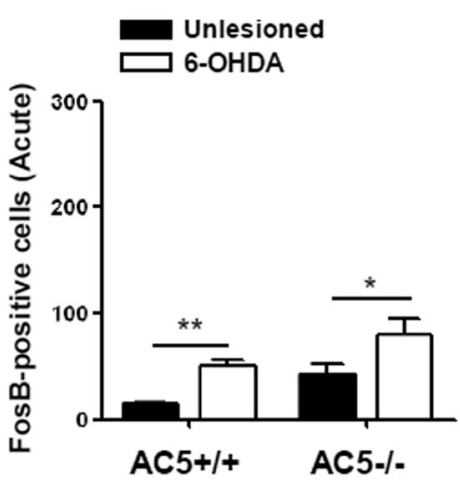

C

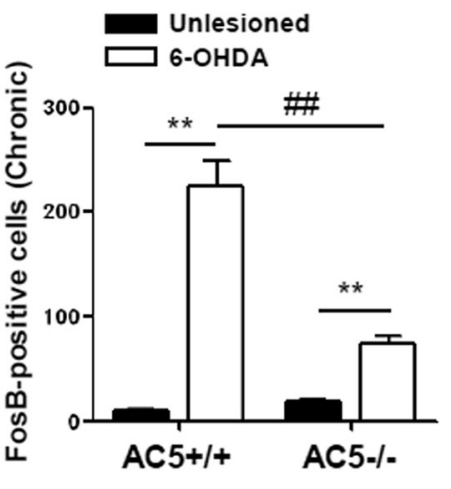

Figure 5. Reduction of FosB/ $\triangle$ FosB-positive cells in the 6-OHDA-lesioned dorsal striatum after long-term treatment with L-DOPA in $A C 5^{-1-}$ mice. $A$, Expression levels of FosB $/ \Delta$ FosB immunoreactivity in the 6-OHDA-lesioned dorsal striata of $\mathrm{AC}^{+/+}$and $\mathrm{AC5}^{-/-}$mice 30 min after the first treatment (short-term treatment) and the last treatment (long-term treatment, 11 d) with $L-D O P A$. FosB $\triangle \triangle$ FosB-positive cells were counted in the lesioned and unlesioned striata of $A C 5^{+1+}$ and $A C 5^{-1-}$ mice. $B$, The number of FosB/ $\Delta$ Fos B-positive cells after the short-term administration of L-DOPA in the unlesioned and lesioned striata of $\mathrm{AC5}^{+/+}$and $\mathrm{AC} 5^{-1-}$ mice $(n=7-5)$. Tw0-way ANOVA with Bonferroni test: effect of genotypes, $F_{(1,20)}=15.62, p=0.0008$; effect of the lesion, $F_{(1,20)}=24.44, p<0.0001$; interaction, $F_{(1,20)}=0.009, p=0.923$. C, The number of FosB/ $\Delta$ FosB-positive cells after long-term L-DOPA treatment in the unlesioned and lesioned striata of $A C 5^{+/+}$and $A C 5^{-1-}$ mice $(n=13-14)$. Two-way ANOVA with Bonferroni test: effect of genotypes, $F_{(1,50)}=35.64, p<0.0001$; effect of the lesion, $F_{(1,50)}=132.51, p<0.0001$; interaction, $F_{(1,50)}=45.17, p<0.0001:^{*} p<0.05$ and ${ }^{* *} p<0.01,6-0$ HDA-lesioned versus unlesioned striata; \#\# $p<0.01$, AC5 ${ }^{+/+}$ versus $\mathrm{AC5}^{-1-}$ mice. Scale bar, $100 \mu \mathrm{m}$. 
A

B
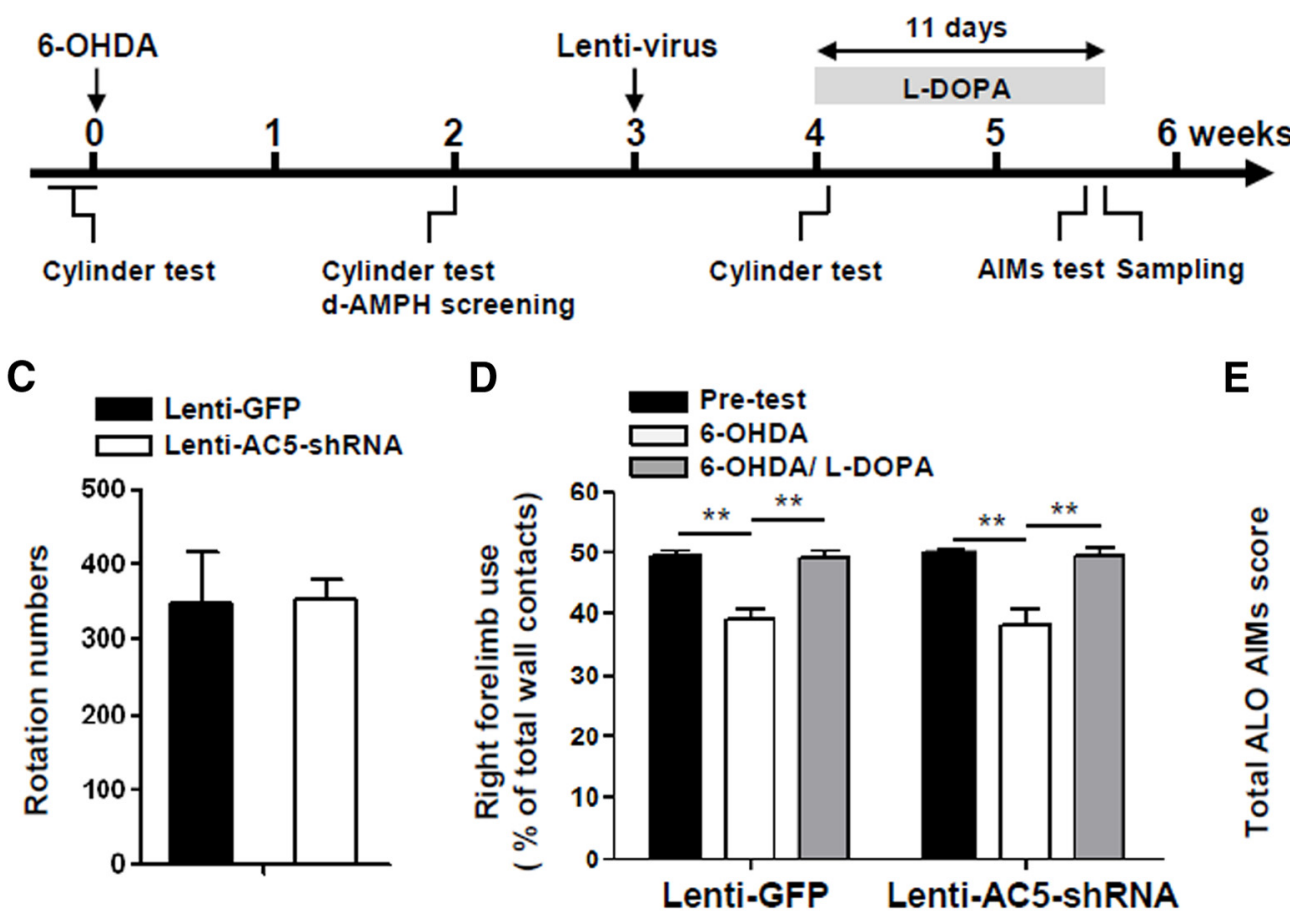

$\mathbf{E}$
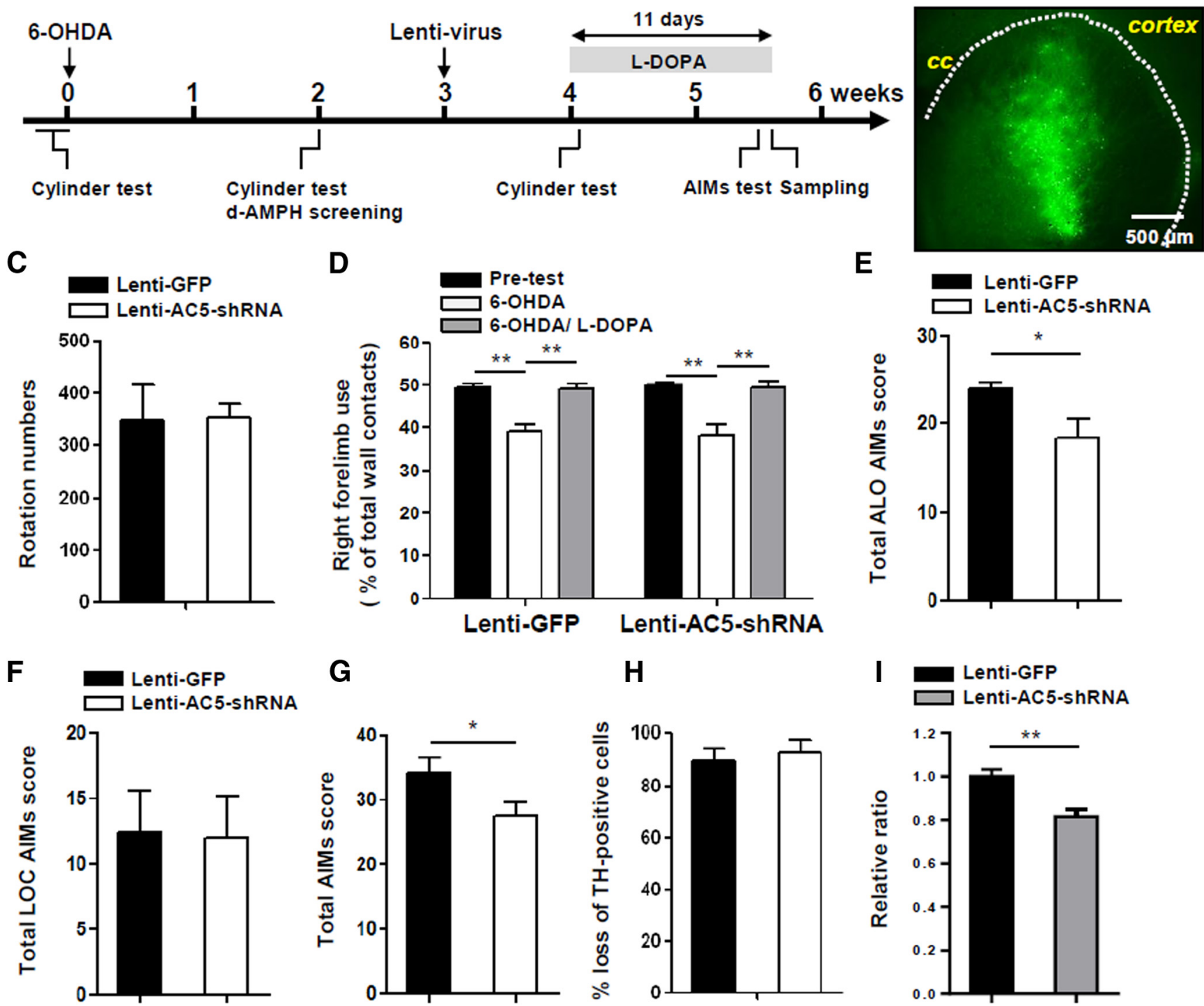

Figure 6. Suppression of AC5 in the dorsal striatum using lenti-AC5 shRNA decreased LID. A, Experimental design for treatment of 6-OHDA lesion, infusion of lenti-AC5 shRNA, following L-DOPA injection and behavioral tests. Lentivirus was unilaterally infused into 6-OHDA-lesioned striatum. B, Photomicrograph showing GFP fluorescence in the dorsal striatum injected with lenti-GFP. cc, Corpus callosum. C, D-AMPH-induced ipsilateral rotations in the two groups (Student's $t$ test, $p>0.05$ ). D, Right forelimb use levels in the cylinder test in mice injected with lenti-GFP or lenti-AC5 shRNA before and after the first treatment with L-DOPA. One-way ANOVA followed by Tukey post hoc test, ${ }^{* *} p<0.01$. $\boldsymbol{E}-\boldsymbol{G}$, ALO AIMs $(\boldsymbol{E})$, LOC AIMs $(\boldsymbol{F})$, and total AIM score $(\boldsymbol{G})$ in mice injected with 6-OHDA followed by injection with lenti-GFP or lenti-AC5 shRNA ( $n=5$ each). Student's $t$ test, ${ }^{*} p<0.05$. $\boldsymbol{H}$, Percentage loss of TH-positive cells in the lesioned SNc in mice injected with 6-0HDA followed by injection with lenti-GFP and lenti-AC5 shRNA. I, Real-time RT-PCR data showing the expression levels of AC5 in the dorsal striatum in wild-type mice injected with lenti-GFP control or lenti-AC5 shRNA. Expression levels were examined $18 \mathrm{~d}$ after viral injection $\left(n=6\right.$ each). Student's $t$ test, ${ }^{* *} p<0.01$.

sions were induced with 6-OHDA, we screened for the mice that showed high levels of ipsilateral rotations in response to D-AMPH (Fig. 6A,C). Selected mice were then separated into two groups for the injection of lenti-GFP-control or lenti-AC5 shRNA. After $7 \mathrm{~d}$ of lentivirus injection, the mice were treated with L-DOPA for $11 \mathrm{~d}$ while behavioral assessments were performed as scheduled (Fig. 6A). With the first administration of L-DOPA, both groups of mice showed behavioral improvements in the cylinder test (Fig. 6D). The mice were then treated with L-DOPA $(20 \mathrm{mg} / \mathrm{kg}$ in combination with $12 \mathrm{mg} / \mathrm{kg}$ benserazide) for an additional $9 \mathrm{~d}$. On the following day, the AIM test was applied. The total ALO AIM score displayed by the lenti-AC5 shRNA group was significantly lower than that of the lenti-GFP group (Fig. 6E), although the LOC composite score was not significantly different (Fig. $6 F$ ). However, the total AIM score exhibited by the lenti-AC5 shRNA group was significantly reduced compared with that of the lentiGFP control group (Fig. 6G). After the AIM test, mice were killed, and it was histologically examined whether the $\mathrm{TH}$-depleted area covered $>80 \%$ of the striatal area and whether the TH levels in the lesioned SNc area were reduced by $>80 \%$ compared with the intact side (Fig. 6H). Lenti-AC5 shRNA-induced downregulation of AC5 in the dorsal striatum was confirmed (Fig. 6I). Together, these analyses suggested that the local inhibition of AC5 in the dorsal striatum was sufficient to suppress LID.

\section{Discussion}

The present study demonstrated the critical role of striatal AC5 in LID with a mouse model of hemi-parkinsonism. The genetically engineered mice lacking AC5and the use of molecular genetic tools enabled us to determine the role of AC5, as well as the 
neurological significance of the CAMP- and ERK-mediated signaling pathway and FosB/ $\Delta$ FosB expression in LID.

The most abundant subtypes of AC in the striatum are AC5 and AC6 (Mons and Cooper, 1994). AC5/6 expression was increased in the denervated striatum of a rat model of hemiparkinsonism (Rangel-Barajas et al., 2011). Mice with severe dyskinesia exhibit increased expression of AC5/6 in the lesioned striatum (Konradi et al., 2004; Rangel-Barajas et al., 2011). These studies have suggested that increased cAMP production in the lesioned striatum might play a role in LID. We observed that AC5 expression was not significantly altered in the denervated striatum of a mouse model, but long-term L-DOPA treatment increased AC5 expression in the lesioned striatum. Although further study is necessary, these results suggest that upregulation of AC5 may be an important mechanism of LID, possibly leading to prolonged $\mathrm{D}_{1} \mathrm{R}$ hypersensitivity. AC5 is a key player in mediating various G-protein-coupled neurotransmitter receptors that are expressed in the dorsal striatum. However, because of an absence of subtype-specific inhibitors for AC5 and the complexity of the $\mathrm{AC} / \mathrm{cAMP}$ system in the striatum, which expresses nine different G-protein-coupled ACs, studies have been hampered in understanding the precise role of AC5 expression in LID. In the present study, we addressed this issue with $\mathrm{AC5} 5^{-1-}$ mice.

Although $\mathrm{AC}^{-1-}$ mice have a complete deletion of AC5 in the striatum, the motor function disturbances caused by 6-OHDA lesions in $\mathrm{AC}^{-1-}$ mice in the grip and cylinder tests were similar to those in wild-type mice (Fig. $1 C, D$ ). In addition, the 6-OHDA-induced motor impairments were recovered by the short-term administration of L-DOPA in both genotypes (Fig. $1 D$ ), whereas the $\mathrm{AC}^{-1-}$ mice exhibited very low levels of AIMs in response to the repeated administration of L-DOPA (Fig. 2A$D)$. These results suggested that AC5 is the key player in the generation of LID and that the supersensitivity of the $\mathrm{D}_{1} \mathrm{R}$ in LID (Bezard et al., 2001; Guigoni et al., 2007; Jenner, 2008; Cenci and Konradi, 2010) and the dopamine-stimulated cAMP production in the striatum of dopamine-depleted rats or Parkinson's disease patients (Hervé et al., 1993; Rangel-Barajas et al., 2011) are likely mediated by AC 5 . In fact, we have previously reported that AC5 is the major effector of the $D_{1} R$ receptor system in the striatum, although treatment with $\mathrm{D}_{1} \mathrm{R}$ agonists in $\mathrm{AC}^{-1-}$ mice partially increases AC activity and induces pharmacobehavioral responses (Lee et al., 2002). In line with these reports is the finding that the suppression of AC5 with lenti-AC5 shRNA in the denervated striatum can decrease the ALO AIM level (Fig. 6).

The prolonged administration of L-DOPA to 6-OHDAlesioned mice results in an overall reduction in the ability of this drug to activate cAMP and ERK signaling (Picconi et al., 2003; Santini et al., 2007; Westin et al., 2007; Cenci and Konradi, 2010; Lebel et al., 2010). The decline in the ability of L-DOPA to promote cAMP/PKA/DARPP32 and ERK signaling occurs specifically in mice with low dyskinesia, but the persistent upregulation of this signaling in mice with high dyskinesia has been revealed (Santini et al., 2007). Furthermore, the pharmacological inhibition of PKA with the PKA inhibitor Rp-cAMP significantly attenuated the emergence of AIMs (Lebel et al., 2010). In the striatum, the loss of dopaminergic innervation results in the development of sensitization to $D_{1} R$ agonists, but this sensitization did not develop in response to the deficiency of the AC5 gene, indicating that AC5 is a major AC in the expression of cAMP/PKA/ERK hypersensitivity to L-DOPA. Although the development of sensitization to L-DOPA on the denervated side was not observed in $\mathrm{AC}^{-1-}$ mice, motor impairment was recovered by the shortterm administration of L-DOPA. This finding suggested that the therapeutic effects of short-term L-DOPA treatment may not require the increases of PKA/ERK signaling in the dopamine denervation model. Although the increased phosphorylation of PKA substrates and ERK1/2 in response to long-term L-DOPA administration was revealed in the DA-denervated striatum of AC5 ${ }^{-1-}$ mice, the short-term treatment with L-DOPA in $\mathrm{AC}^{-1-}$ mice did not cause hypersensitivity of PKA/ERK signaling in the DAdenervated striatum, compared with the intact striatum.

The transcription factor Fos $/ \Delta$ FosB is a mediator of maladaptive neuroplasticity in animal models of PD and in LID (Andersson et al., 1999; Pavón et al., 2006; Cao et al., 2010). Compared with both controls and nondyskinetic cases, the dyskinetic group showed a higher density of FosB/ $\Delta$ FosBimmunoreactive cells in the posterior putamen (Andersson et al., 1999; Lindgren et al., 2011). FosB/ $\Delta$ FosB expression was increased in the dopamine-depleted striatum (Andersson et al., 1999; Pavón et al., 2006). Moreover, the induction of FosB/ $\Delta$ FosB expression occurs in neurons that express $\mathrm{D}_{1} \mathrm{Rs}$ (Pavón et al., 2006). In fact, FosB $/ \Delta$ FosB expression was markedly increased after long-term L-DOPA treatment in the dopaminedepleted striatum of wild-type mice (Fig. 5). In contrast, FosB/ $\triangle$ FosB induction in response to long-term L-DOPA treatment in $\mathrm{AC5}^{-1-}$ mice was similar to the levels that were induced by a single exposure (Fig. 5). These results suggested that the hypersensitivity of FosB $/ \Delta$ FosB expression in LID was primarily mediated by AC5.

The results of the present study demonstrated that AC5 KO suppressed the activation of PKA, ERK, MSK1, and histone H3, which are key molecules in LID, suggesting that AC5 functions as an upstream mediator of LID. Previous studies have suggested that $\mathrm{D}_{1}$ Rs (Westin et al., 2007), cAMP/PKA (Lebel et al., 2010), DARPP32 (Santini et al., 2007), and ERK (Santini et al., 2007) have a critical role in the expression of LID. Interfering with any of these signaling cascades decreased LID in the rodent models. Because AC5 mediates the signaling effects of $\mathrm{D}_{1} \mathrm{R}, \mathrm{cAMP} / \mathrm{PKA}$, and ERK, AC5 ${ }^{-1-}$ mice exhibited a profound suppression of LID. Moreover, the local suppression of the AC5 gene on the lesioned side of the striatum reduced AIMs levels in mice without affecting the anti-parkinsonian efficacy of L-DOPA. It will be interesting to investigate whether the direct inhibition of AC5 provides therapeutic benefits for the treatment of LID in patients with PD.

\section{References}

Alcacer C, Santini E, Valjent E, Gaven F, Girault JA, Hervé D (2012) G $\alpha_{\text {olf }}$ mutation allows parsing the role of cAMP-dependent and extracellular signal-regulated kinase-dependent signaling in L-3,4-dihydroxyphenylalanineinduced dyskinesia. J Neurosci 32:5900-5910. CrossRef Medline

Andersson M, Hilbertson A, Cenci MA (1999) Striatal fosB expression is causally linked with 1-DOPA-induced abnormal involuntary movements and the associated upregulation of striatal prodynorphin mRNA in a rat model of Parkinson's disease. Neurobiol Dis 6:461-474. CrossRef Medline

Aubert I, Guigoni C, Håkansson K, Li Q, Dovero S, Barthe N, Bioulac BH, Gross CE, Fisone G, Bloch B, Bezard E (2005) Increased D1 dopamine receptor signaling in levodopa-induced dyskinesia. Ann Neurol 57:17-26. CrossRef Medline

Bezard E, Brotchie JM, Gross CE (2001) Pathophysiology of levodopainduced dyskinesia: potential for new therapies. Nat Rev Neurosci 2:577588. CrossRef Medline

Brami-Cherrier K, Valjent E, Hervé D, Darragh J, Corvol JC, Pages C, Arthur SJ, Girault JA, Caboche J (2005) Parsing molecular and behavioral effects of cocaine in mitogen- and stress-activated protein kinase-1deficient mice. J Neurosci 25:11444-11454. CrossRef Medline

Cao X, Yasuda T, Uthayathas S, Watts RL, Mouradian MM, Mochizuki H, Papa SM (2010) Striatal overexpression of DeltaFosB reproduces chronic 
levodopa-induced involuntary movements. J Neurosci 30:7335-7343. CrossRef Medline

Cenci MA, Konradi C (2010) Maladaptive striatal plasticity in L-DOPAinduced dyskinesia. Prog Brain Res 183:209-233. CrossRef Medline

Corvol JC, Muriel MP, Valjent E, Féger J, Hanoun N, Girault JA, Hirsch EC, Hervé D (2004) Persistent increase in olfactory type G-protein $\alpha$ subunit levels may underlie $\mathrm{D}_{1}$ receptor functional hypersensitivity in Parkinson disease. J Neurosci 24:7007-7014. CrossRef Medline

Darmopil S, Martín AB, De Diego IR, Ares S, Moratalla R (2009) Genetic inactivation of dopamine D1 but not D2 receptors inhibits L-dopainduced dyskinesia and histone activation. Biol Psychiatry 66:603-613. CrossRef Medline

Deak M, Clifton AD, Lucocq LM, Alessi DR (1998) Mitogen- and stressactivated protein kinase-1 (MSK1) is directly activated by MAPK and SAPK2/p38, and may mediate activation of CREB. EMBO J 17:44264441. CrossRef Medline

Fasano S, Bezard E, D’Antoni A, Francardo V, Indrigo M, Qin L, Doveró S, Cerovic M, Cenci MA, Brambilla R (2010) Inhibition of Ras-guanine nucleotide-releasing factor 1 (Ras-GRF1) signaling in the striatum reverts motor symptoms associated with L-dopa-induced dyskinesia. Proc Natl Acad Sci U S A 107:21824-21829. CrossRef Medline

Gerfen CR, Miyachi S, Paletzki R, Brown P (2002) $D_{1}$ dopamine receptor supersensitivity in the dopamine-depleted striatum results from a switch in the regulation of ERK1/2/MAP kinase. J Neurosci 22:5042-5054. Medline

Glatt CE, Snyder SH (1993) Cloning and expression of an adenylyl cyclase localized to the corpus striatum. Nature 361:536-538. CrossRef Medline

Granado N, O’Shea E, Bove J, Vila M, Colado MI, Moratalla R (2008) Persistent MDMA-induced dopaminergic neurotoxicity in the striatum and substantia nigra of mice. J Neurochem 107:1102-1112. CrossRef Medline

Greengard P, Allen PB, Nairn AC (1999) Beyond the dopamine receptor: the DARPP-32/protein phosphatase-1 cascade. Neuron 23:435-447. CrossRef Medline

Guigoni C, Doudnikoff E, Li Q, Bloch B, Bezard E (2007) Altered D(1) dopamine receptor trafficking in parkinsonian and dyskinetic nonhuman primates. Neurobiol Dis 26:452-463. CrossRef Medline

Hemmings HC Jr, Williams KR, Konigsberg WH, Greengard P (1984) DARPP-32, a dopamine- and adenosine $3^{\prime}: 5^{\prime}$-monophosphate-regulated neuronal phosphoprotein. I. Amino acid sequence around the phosphorylated threonine. J Biol Chem 259:14486-14490. Medline

Hervé D, Lévi-Strauss M, Marey-Semper I, Verney C, Tassin JP, Glowinski J, Girault JA (1993) G(olf) and Gs in rat basal ganglia: possible involvement of $G($ olf $)$ in the coupling of dopamine $D_{1}$ receptor with adenylyl cyclase. J Neurosci 13:2237-2248. Medline

Hervé D, Le Moine C, Corvol JC, Belluscio L, Ledent C, Fienberg AA, Jaber M, Studler JM, Girault JA (2001) Galpha(olf) levels are regulated by receptor usage and control dopamine and adenosine action in the striatum. J Neurosci 21:4390-4399. Medline

Jenner P (2008) Molecular mechanisms of L-DOPA-induced dyskinesia. Nat Rev Neurosci 9:665-677. CrossRef Medline

Kim KS, Lee KW, Lee KW, Im JY, Yoo JY, Kim SW, Lee JK, Nestler EJ, Han PL (2006) Adenylyl cyclase type 5 (AC5) is an essential mediator of morphine action. Proc Natl Acad Sci U S A 103:3908-3913. CrossRef Medline

Kim KS, Lee KW, Baek IS, Lim CM, Krishnan V, Lee JK, Nestler EJ, Han PL (2008) Adenylyl cyclase- 5 activity in the nucleus accumbens regulates anxiety-related behavior. J Neurochem 107:105-115. CrossRef Medline

Kim KS, Kim H, Park SK, Han PL (2012a) The dorsal striatum expressing adenylyl cyclase- 5 controls behavioral sensitivity of the righting reflex to high-dose ethanol. Brain Res 1489:27-36. CrossRef Medline

Kim KS, Kang YM, Kang Y, Park TS, Park HY, Kim YJ, Han BS, Kim CH, Lee CH, Ardayfio PA, Han PL, Jung BH, Kim KS (2014) Pitx3 deficient mice as a genetic animal model of co-morbid depressive disorder and parkinsonism. Brain Res 1552:72-81. CrossRef Medline

Kim TK, Han HE, Kim H, Lee JE, Choi D, Park WJ, Han PL (2012b) Expression of the plant viral protease NIa in the brain of a mouse model of Alzheimer's disease mitigates $A \beta$ pathology and improves cognitive function. Exp Mol Med 44:740-748. CrossRef Medline

Konradi C, Westin JE, Carta M, Eaton ME, Kuter K, Dekundy A, Lundblad M, Cenci MA (2004) Transcriptome analysis in a rat model of L-DOPAinduced dyskinesia. Neurobiol Dis 17:219-236. CrossRef Medline

Lebel M, Chagniel L, Bureau G, Cyr M (2010) Striatal inhibition of PKA prevents levodopa-induced behavioural and molecular changes in the hemiparkinsonian rat. Neurobiol Dis 38:59-67. CrossRef Medline
Lee KW, Hong JH, Choi IY, Che Y, Lee JK, Yang SD, Song CW, Kang HS, Lee JH, Noh JS, Shin HS, Han PL (2002) Impaired D2 dopamine receptor function in mice lacking type 5 adenylyl cyclase. J Neurosci 22:7931-7940. Medline

Lindgren HS, Rylander D, Iderberg H, Andersson M, O'Sullivan SS, Williams DR, Lees AJ, Cenci MA (2011) Putaminal upregulation of FosB/ $\Delta$ FosBlike immunoreactivity in Parkinson's disease patients with dyskinesia. J Parkinsons Dis 1:347-357. CrossRef Medline

Lundblad M, Andersson M, Winkler C, Kirik D, Wierup N, Cenci MA (2002) Pharmacological validation of behavioural measures of akinesia and dyskinesia in a rat model of Parkinson's disease. Eur J Neurosci 15:120-132. CrossRef Medline

Lundblad M, Usiello A, Carta M, Håkansson K, Fisone G, Cenci MA (2005) Pharmacological validation of a mouse model of $\mathrm{L}$-dopa-induced dyskinesia. Exp Neurol 194:66-75. CrossRef Medline

Mons N, Cooper DM (1994) Adenylyl cyclase mRNA expression does not reflect the predominant $\mathrm{Ca} 2+/$ calmodulin-stimulated activity in the hypothalamus. J Neuroendocrinol 6:665-671. CrossRef Medline

Nowak SJ, Corces VG (2004) Phosphorylation of histone H3: a balancing act between chromosome condensation and transcriptional activation. Trends Genet 20:214-220. CrossRef Medline

Pavón N, Martín AB, Mendialdua A, Moratalla R (2006) ERK phosphorylation and FosB expression are associated with L-DOPA-induced dyskinesia in hemiparkinsonian mice. Biol Psychiatry 59:64-74. CrossRef Medline

Paxinos G, Franklin K (2008) The mouse brain in stereotaxic coordinates. New York: Academic.

Picconi B, Centonze D, Håkansson K, Bernardi G, Greengard P, Fisone G, Cenci MA, Calabresi P (2003) Loss of bidirectional striatal synaptic plasticity in L-DOPA-induced dyskinesia. Nat Neurosci 6:501-506. CrossRef Medline

Rangel-Barajas C, Silva I, García-Ramírez M, Sánchez-Lemus E, Floran L, Aceves J, Erlij D, Florán B (2008) 6-OHDA-induced hemiparkinsonism and chronic L-DOPA treatment increase dopamine D1-stimulated $[(3) \mathrm{H}]$-GABA release and $[(3) \mathrm{H}]$-cAMP production in substantia nigra pars reticulata of the rat. Neuropharmacology 55:704-711. CrossRef Medline

Rangel-Barajas C, Silva I, Lopéz-Santiago LM, Aceves J, Erlij D, Florán B (2011) L-DOPA-induced dyskinesia in hemiparkinsonian rats is associated with up-regulation of adenylyl cyclase type V/VI and increased GABA release in the substantia nigra reticulate. Neurobiol Dis 41:51-61. CrossRef Medline

Santini E, Valjent E, Usiello A, Carta M, Borgkvist A, Girault JA, Hervé D, Greengard P, Fisone G (2007) Critical involvement of cAMP/DARPP-32 and extracellular signal-regulated protein kinase signaling in L-DOPAinduced dyskinesia. J Neurosci 27:6995-7005. CrossRef Medline

Seo JS, Park JY, Choi J, Kim TK, Shin JH, Lee JK, Han PL (2012) NADPH oxidase mediates depressive behavior induced by chronic stress in mice. J Neurosci 32:9690-9699. CrossRef Medline

Sindreu CB, Scheiner ZS, Storm DR (2007) Ca2+-stimulated adenylyl cyclases regulate ERK-dependent activation of MSK1 during fear conditioning. Neuron 53:79-89. CrossRef Medline

Snyder GL, Allen PB, Fienberg AA, Valle CG, Huganir RL, Nairn AC, Greengard P (2000) Regulation of phosphorylation of the GluR1 AMPA receptor in the neostriatum by dopamine and psychostimulants in vivo. J Neurosci 20:4480-4488. Medline

Soghomonian JJ, Laprade N (1997) Glutamate decarboxylase (GAD67 and GAD65) gene expression is increased in a subpopulation of neurons in the putamen of Parkinsonian. Synapse 27:122-132. CrossRef Medline

Soloaga A, Thomson S, Wiggin GR, Rampersaud N, Dyson MH, Hazzalin CA, Mahadevan LC, Arthur JS (2003) MSK2 and MSK1 mediate the mitogenand stress-induced phosphorylation of histone H3 and HMG-14. EMBO J 22:2788-2797. CrossRef Medline

Surmeier DJ, Ding J, Day M, Wang Z, Shen W (2007) D1 and D2 dopaminereceptor modulation of striatal glutamatergic signaling in striatal medium spiny neurons. Trends Neurosci 30:228-235. CrossRef Medline

Westin JE, Vercammen L, Strome EM, Konradi C, Cenci MA (2007) Spatiotemporal pattern of striatal ERK1/2 phosphorylation in a rat model of L-DOPA-induced dyskinesia and the role of dopamine D1 receptors. Biol Psychiatry 62:800-810. CrossRef Medline

Zhuang X, Belluscio L, Hen R (2000) G(olf)alpha mediates dopamine $\mathrm{D}_{1}$ receptor signaling. J Neurosci 20:RC91. Medline 